\title{
Teachers' Perception of Advantages and Disadvantages of Kahoot!
}

\author{
Abouzar Rajabpour \\ Correspondence: Abouzar Rajabpour, Freelance Researcher, Oman. \\ Received: September 2, 2021 \\ Accepted: November 21, 2021 \\ Online Published: November 22, 2021 \\ doi:10.5430/elr.v10n4p49 \\ URL: https://doi.org/10.5430/elr.v10n4p49
}

\begin{abstract}
Many instructors around the world have been using different Game-based Student Response Systems due to the rise in the variety and availability of digital educational and commercial games. Kahoot, one of the most popular among these systems, provides a game experience by combining theory of intrinsic motivation and game-flow with the help of audio/visual aids. In spite of the numerous attempts to evaluate this game-based tool according, limited research has focused on teachers' perceptions of the potential strengths and weaknesses of Kahoot, specifically in GCC countries. Employing focus group interviews, this study attempts to shed some light on the potential advantages and disadvantages of Kahoot by gathering the views of teachers who work at the Center for Preparatory Studies at a university in Oman. Results indicate that although teachers believe that Kahoot is qualified with several positive features, it still suffers from several disadvantages in which it can definitely improve.
\end{abstract}

Keywords: learners' engagement, kahoot, motivation, teachers' perceptions

\section{Introduction}

It is acknowledged that keeping students' motivation, engagement, and concentration over time in a lecture is a big challenge. This lack of motivation can have a negative effect on learning outcomes and the atmosphere in the classroom (Liu, Bridgeman \& Adler, 2012). This challenge is even bigger in higher education where there are big classes with little interaction. There are different ways to make lectures more interactive some of which are forming groups, using audience responses (systems), using written materials, organizing discussions, using simulations and role-plays, videos, audiovisual aids, and effective presentation skills (Steinert \& Snell, 1999).

Among the many ways utilized for teaching purposes is the use of Classroom Response Systems (CRS), else known as Audience Response Systems (ARS) or Students Response Systems (SRS) (Muncy \& Eastman, 2012). These systems increase questioning and answering in the classroom and provide instant feedback to teachers and learners (Siau, Sheng, \& Fui-Hoon, 2006). They have a positive effect on classroom dynamics, student and teacher perceptions, and learning performance (Caldwell, 2007). Another furtherance in educational technology is gamebased learning. Well-designed video games are efficient means for learning because they inspire and engage the players in such a way that they learn without even noticing it (Gee, 2003). Educational games have proven to be advantageous for academic accomplishment, motivation, and classroom dynamics (Sharples, 2000). Several Student Response Systems have introduced game features to improve students' engagement, for example, Socrative (Dervan, 2014) and Quizlet (Chien, 2015). Gaming is naturally stimulating because it gives learners the opportunity to gain skills and knowledge, by making use of entertainment and weaving it within learning environments (Gee, 2003; Paraskeva, Mysirlaki, \& Papagianni, 2010).

Using digital games in education or digital game-based learning (DGBL) is becoming increasingly popular because there is a rise in variety, availability and use of digital educational and commercial games (Pivec, 2007). Research studies and conceptual literature show that video or digital games in particular have great motivational and educational benefits (Paraskeva et al., 2010). Currently, digital educational games (DEGs) are being recognized as effective means to instruction. Despite this, they have not been utilized to their optimal potential in higher education (Law \& Sun, 2012). In order to address this gap and implement DGBL more widely in higher education, it is important to research how using these games in higher education curriculum may influence learners' experiences and learning.

Kahoot is the first Student Response System designed to provide a game experience using game design principles in combination with the theory of intrinsic motivation (Malone, 1981) and game-flow (Sweetser \& Wyeth, 2005). Kahoot is, hence, using a combination of audience responses and audio/visual aids. Although other SRSs include 
game features, only Kahoot has been designed based on a video game (Wang, 2015). The prime concept of Kahoot is to interfuse an SRS and gaming into one learning platform. The goal of Kahoot is to improve learning performance and classroom dynamics by enhancing engagement, motivation, joy, and concentration. It is employed in two ways: to evaluate students' knowledge in the form of a formative assessment or as a break from traditional classroom activities (Ismail \& Mohammad, 2017). It is now among the most popular game-based learning platforms, with over 70 million monthly active unique users. Just in 2019, over 2.5 billion people with more than 200 different nationalities have played Kahoot (Vick, 2019).

Since the platform was released in 2013, there have been many published studies on the relationship between Kahoot and learning outcomes (Fotaris, Mastoras, Leinfellner \& Rosunally, 2016), classroom dynamics (Aktekin, Çelebi \& Aktekin, 2018; Licorish, Owen, Daniel, \& George, 2018; Wichadee \& Pattanapichet, 2018), students' anxiety (Lee, et al., 2019; Licorish et al., 2018; Turan \& Meral, 2018), students' perceptions (Budiati, 2017; Tsymbal, 2018) and teachers' perceptions (Bicen \& Kocakoyun, 2018; Yapıc1 \& Karakoyun, 2017) in various contexts and concerning different academic subjects. Most of these studies have focused on the positive attributes of Kahoot (Licorish et al., 2017 \& 2018; Wang \& Tahir, 2020). Nonetheless, as Al Awadhi (2019) mentions, many of the issues connected to Kahoot is reported to be connectivity and access problems which are not drawbacks of the platform. Another issue with the existing literature is that a big portion of the advantages or disadvantages mentioned in the literature are extracted from the students' points of views (Bicen \& Kocakoyun, 2018; Saracoglu \& Kocabatmaz, 2019). Little attention is given the ideas of educators about the potential strengths and weaknesses of this popular online tool.

In spite of the numerous studies on Kahoot, there is still a gap pertaining to qualitative studies targeting teachers' perceptions of the advantages and disadvantages of this popular tool in GCC countries. Having teachers' perception on this topic can tackle any potential issues in Kahoot platform itself and also pave the way for its efficient implementation in the classes. Not having a conspicuous image of what teachers actually think about Kahoot might lead to misinterpretations about this tool. Furthermore, teachers' perceptions help us discover whether Kahoot quizzes are just a means of fun and entertainment for students or they are valuable tools with academic aims. Accordingly, the present study tries to explore how Center for Preparatory Studies (CPS) teachers at a university in Oman perceive the potential strengths and drawbacks of Kahoot using a qualitative approach.

Understanding the potential benefits and more importantly the probable drawbacks of this popular platform can help all users including teachers and students to maximize its efficiency and make the best out of it. This study would serve as a complement for the insufficient literature on teachers' actual ideas about Kahoot in the literature, a cornerstone for further research on how to improve the effectiveness of Kahoot in the classes and a hint for Kahoot designers on how to mend the likely inefficiencies in this popular teaching tool.

\section{Literature review}

\subsection{Game-based Students Response Systems (GSRS)}

With the pervasion of mobile devices and the ubiquity of Bring Your Own Device (BYOD) in contemporary classroom teaching, technology is more incorporated into several aspects of classrooms in order to ease assessments, improve student engagement, motivation and learning (Prensky, 2001). In line with these changes, there has recently been a shift from common student response systems (SRS) such as "clickers" and "zappers" to more contemporary game-based student response systems (GSRS) such as Socrative and Kahoot (Wang, 2015). In GSRS, the teacher designs interactive quizzes that are projected as regular lecture slides and students answer the questions using a web browser on their digital devices in a gamified situation. The teachers can add images, videos and also manage the audio and pace of the play. Students are awarded points for answering questions correctly and fast. These points are displayed on the screen during the game which inspires students to get to the top of the leader board.

Previous research shows that integrating GSRS (e.g., Kahoot) into regular classrooms improves student engagement (Wang, 2015). Earlier research also suggests that GSRS enhance classroom dynamics and enrich students' interactions with their peers and teachers (Rosas, Nussbaum, Cumsille, Marianov, Correa \& Flores, 2003). What is more, GSRS can motivate the shy students who rarely participate in class discussions (Wang, 2015). These systems also ameliorate overall class attendance.

\subsection{Kahoot}

Kahoot is a game-based student response system, initiated in 2006 at the Norwegian University of Science and Technology (NTNU). Kahoot is a tool for making quizzes where teachers can add pictures and YouTube videos to the questions. They can also publish and share their own quizzes, and even edit the ones made by others. When teachers want to run Kahoot in the classroom, they need to launch it in a web browser on a computer system 
connected to a large screen so that the students clearly see what is displayed from the teacher's computer. The students are asked to go to https://kahoot.it in a web-browser on their own mobiles. They do not need to have an account to play. To play the game, they just enter a game pin and a nickname.

As the quiz starts, the questions along with the answers are presented on the screen, and the students choose the same color/symbol for the correct answer. On the screen, there is a timer showing the remaining time to answer the questions and also a counter showing the number of students that have answered the question. During the test, Kahoot uses graphics, music and sounds to make it more playful and competitive for the students. After each question, a summary of how the students have answered it is displayed as well as a scoreboard of the top five players. Additionally, the players get simultaneous feedback on their questions including correctness, number of points, their rankings in the class, the points needed to reach the student ranked above, and the correct answer if the student has not chosen the right one. At the end of the game, the three top students' nicknames and points will be shown on the large screen.

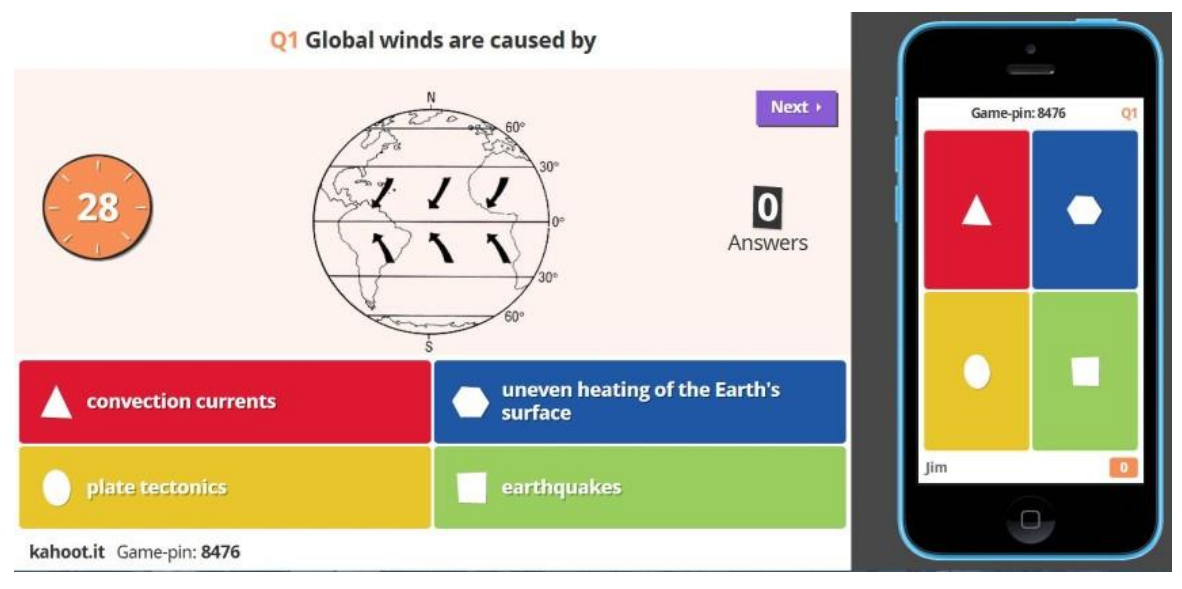

Figure 1. Screenshot of teacher and student mobile device for Kahoot (Adopted from Celik, Akcetin, Asmali, 2016)

\subsection{Previous Studies on Kahoot}

Since Kahoot was launched in 2013, numerous scholars have explored it in different contexts, for example, Taiwan (Chiang, 2020), Turkey (Bicen \& Kocakoyun, 2018) and New Zealand (Licorish et al., 2018). Furthermore, researchers have targeted the application of Kahoot in teaching various languages such as German (Chumairok \& Ardiyani, 2020) and Chinese (Liu \& Wang, 2017), and different language skills like vocabulary (Hadijah, Pratolo \& Rondiyah, 2020) and pronunciation (Yürük, 2020). Some have even gone further and done research on the use of Kahoot in training academic subjects, for example, microbiology (Mohan, Nambiar, \& Arvindakshan, 2018).

In their literature review, Wang and Tahir (2020) encapsulate all the previous studies on Kahoot. According to them, the studies on Kahoot fall into five basic categories: Learning effect of using Kahoot, the effect of Kahoot on classroom dynamics, the relationship between Kahoot and student anxiety, students' perceptions and teachers' perceptions. They reported 48 papers investigating the learning outcome of using Kahoot in education, 34 papers describing how Kahoot affects the classroom dynamics and 14 articles discovering any potential connection between using Kahoot and students' anxiety. An overwhelming number of studies have been carried out on students' perception of Kahoot, with over 80 academic research articles published on the subject and other closely related issues. On the other hand, studies on teachers' perceptions, which are no less important, have received little systematic attention. Their views can help us have a better understanding of this new technological tool, use is in a more efficient way and get closer to the initial objectives that Kahoot was meant to reach.

\subsection{Teachers' Perceptions of Kahoot}

Despite its significance and recognition in the field, teachers' perceptions were studied in a dozen studies or so, as stated earlier, of which only two are directly related to this concept. Some of these studies merely focused on students' positive perceptions about Kahoot. Bicen and Kocakoyun (2018) concluded that students perceive Kahoot very positively because it increases their interest, motivation, understanding and encouragement. Susanti (2017) found that Kahoot helps students express their point of view in class and wakes them up from their slumber in class. In the same vain, Nkhoma, Nkhoma, Thomas and Tu (2018) reported that Kahoot provides feedback, helps check students' understanding and give the lecturer the opportunity to engage with a large number of students. Furthermore, 
Kahoot is also reported to increase class participation (Parra-Santos, Molina-Jorda, Casanova-Pastor \& MaioranoLauria, 2018) and reduce teacher's workload (de Sousa, 2018). The two other articles noted that team-based Kahoots assist learners to share knowledge (Atherton, 2018), and well-designed Kahoots enhance student engagement, motivation and learning (Smith \& Brauer, 2018).

In the first study where teachers' actual perceptions were of concern, 15 pre-service teachers in biology education in Turkey participated. Using a motivation scale and interviews, Yapıc1 and Karakoyun (2017) found that teachers' motivation increased significantly after starting to use Kahoot. The participants of the study stated that Kahoot entertained them, resulted in better teaching, and reinforced their knowledge. Only two negative comments were reported in their study: one about students' disappointment being at the bottom of the list and the other one pertaining to the lack of technical skills among students. The main drawback of this article is the insufficient expertise among the participants of the study in teaching, and in using Kahoot in actual classrooms as well. Moreover, this article investigates teachers' perceptions who are specialized in biology and that makes the generalizability to other fields and contexts difficult.

In another study targeting teachers' perceptions of Kahoot, Batsila and Tsihouridis (2018) analyzed the views of 149 secondary education teachers in Greece. The participants of their study were introduced to Kahoot and were asked to design their own tasks. After completing the task, semi-structured questionnaires were delivered to teachers and also, a semi-structured focus group discussion was conducted with 25 randomly selected teachers. The findings suggested that Kahoot was easy to use, motivating for learners, supportive and exciting for teachers and a useful assessment tool to evaluate students' knowledge.

According to literature, it is clear that Kahoot is a useful tool for both teachers and students in various aspects. In spite of the abundant work done on this topic all over the world, no study has been carried out in this regard in GCC where according to previous research, Kahoot is a common tool in EFL classes (Al Awadhi, 2019). According to Al Awadhi, the topic is less explored in large academic settings in higher education in the Middle East. To address this gap in the literature, the present study tries to explore how English teachers at a university in Oman actually perceive Kahoot.

\section{Method}

\subsection{Design and Instrumentation}

Previous research suggests that in order to explore users' experience with game-based technology, it might be better suited to apply qualitative approaches rather than quantitative ones (Nacke, Drachen \& Göbel, 2010). Focus group interviews were used to elicit authentic data from the participants. After customizing the setting in Mentimeter, the participant teachers were able to insert their comments anonymously only once. Some of them used their phones while others made use of the computer systems in the location of a professional development workshop, entitled Maximizing Kahoot's efficiency in EFL classes. After all comments were submitted, a focus group discussion was held on each and every comment. The discussion lasted for almost half an hour and was recorded using a personal recording device. The recordings were transcribed (thick description was utilized) later on and served as a supplement for the initial comments in Mentimeter.

\subsection{Participants}

Having received the permission from the Professional Development Committee to run the study at the center, we sent out an invitation email to all lecturers of the center to see if they were willing to participate in the study, and if they use Kahoot in their classes. Out of 226 English lecturers at the center, 13 lecturers ( 7 males and 6 females) expressed their willingness and met the second condition, i.e., using Kahoot in their English classes at the center. They also expressed their consent verbally before starting the focus group interviews. Then, they were requested to participate in a workshop, scheduled by the Professional Development Committee, held at one of the labs in the center. Finally, they were asked to take part in focus group interviews to give their opinions on the potential strengths and weaknesses of Kahoot right after the workshop. The participants expressed their ideas confidentially through Mentimeter. Prior to the focus group interviews, they reported to have been using Kahoot for an average of 45 minutes on a weekly basis in their English classes in the Foundation Program at a university in Oman. To add more details about the participants, the researchers enquired the participants' ages, nationalities, educational history, and teaching experience. Their age ranges between 33 and 42 years old, with an average age of 39. They come from different nationalities including American, British, Indian, Iranian and Sudanese. Eleven participants hold an M.A. in ELT and the remaining 2 hold a Ph.D. in this field of specialty. On average, they have been teaching English for about 10 years in general, and 4 years at the center. 


\subsection{Data Collection and Analysis}

To gather the data, the participants of the study were asked to go to www.menti.com, enter the code to access the platform of Mentimeter. It is a commercial student response system that uses a freemium approach, interfuses wireless hardware with presentation software. (Radolph, 2018). Due to the fact that Mentimeter is cloud-based and open-source, the audience can bring their own devices and use their smartphones, tablets or laptops for participation. What is more, it is device agnostic, i.e. no hardware, app or installation is required which makes it a perfect tool for live audience feedback, mood measurement or live polling. For each research question, a separate slide was created on Mentimeter. Figure 2 demonstrates a schematic view of what an actual Mentimeter output would look like. Thanks to the Mentimeter's customizated platform, the participants could suggest several ideas. It is worth mentioning that the participants of the study expressed their consent not only to participate in the study, but also they agreed to have their comments publicized. Due to the security configuration of Mentimeter, only the researchers would have access to the results for the data analysis.

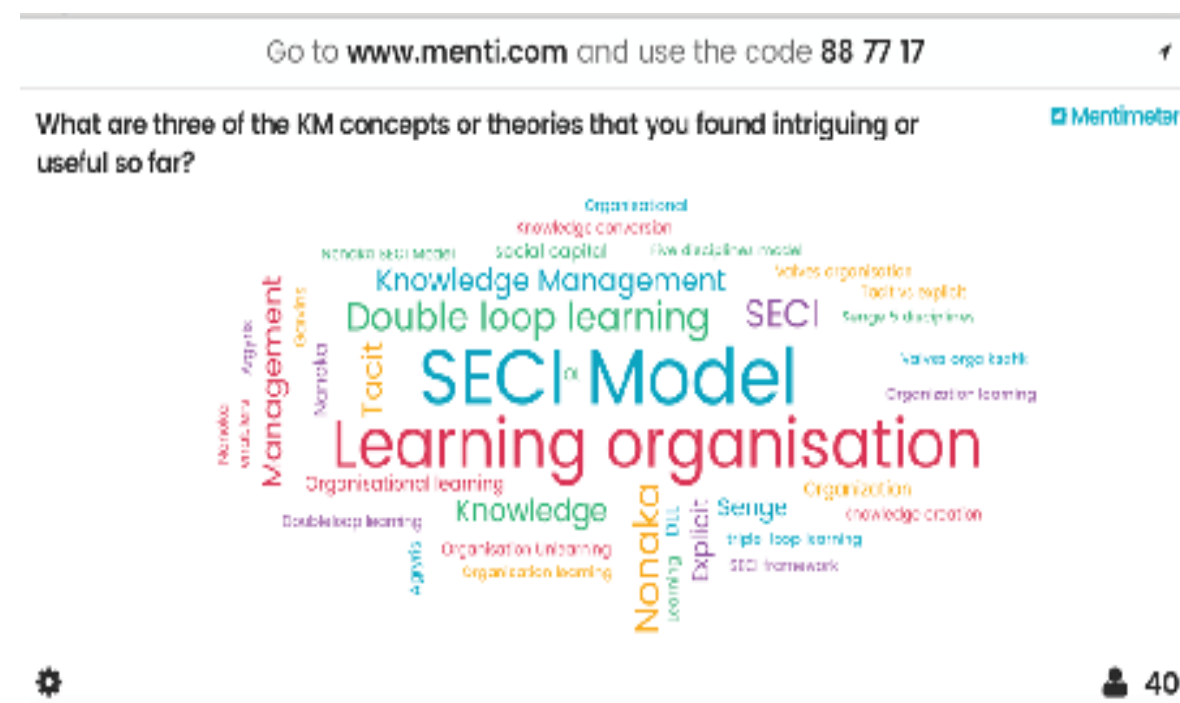

Figure 2. Mentimeter word cloud. Adopted from (Radolph, 2018)

The responses to the two open-ended questions, gathered through Mentimeter, were analyzed further for the existing common themes in participants' comments. These themes or codes were categorized based on word repetition technique (Ryan \& Bernard, 2003). To enrich the results of the study, the notes from the discussion session on comments were also added to the findings.

\section{Findings and Discussion}

\subsection{Advantages of Kahoot}

The purpose of this study was to find out what CPS teachers actually perceive of the merits and demerits of Kahoot. After discarding the lexical words, the researchers filtered the remaining content words towards topic-specific terminologies in the word cloud (Figure 3). These features were chosen to be included in the subsequent analysis.

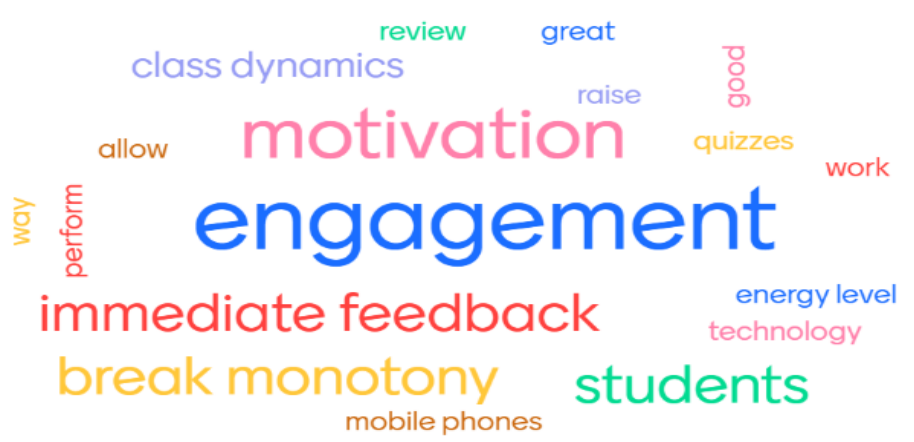

Figure 3. Word cloud of the qualitative data regarding Kahoot advantages 
Table 1 summarizes these common features with regard to the advantages of Kahoot. Eight teachers commented that students' engagement is the most prominent strength of Kahoot. Six participants stated that its ability to break up the monotony of the class and change in classroom dynamics is its salient advantage. Motivation took the third place in terms of frequency. Five teachers believed that Kahoot is quite motivating for students. Three teachers suggested that immediate result presentation is the main benefit of Kahoot. Effect on energy level and ease of review are the other positive features of Kahoot.

Table 1. Teachers' comments on advantages of Kahoot

\begin{tabular}{lc}
\hline Comment & Count \\
\hline Students' engagement & 6 \\
Class dynamics & 4 \\
Motivation & 3 \\
Immediate feedback & 2 \\
Energy level & 1 \\
Review & 1 \\
\hline Total & 17 \\
\hline
\end{tabular}

The first and most salient characteristic of Kahoot identified in the interviews is its capability of engaging students in classroom activities and ambience. Teachers commented, 'keeps students engaged', 'It is a great way to keep the students engaged'. This finding complies with previous research findings in the field (Aktekin, Çelebi, \& Aktekin, 2018; Chaiyo \& Nokham, 2017; Licorish et al., 2018; Quadir, Chen, \& Zhang, 2018; Wang, Zhu \& Sætre, 2016; Wichadee \& Pattanapichet, 2018). The Challenge in Kahoot, where the correct answers are hidden until all students have given their answer, is one of those interesting components of Kahoot which creates a suspension leading to higher levels of engagement in learners (Chaiyo \& Nokham, 2017; de Sousa, 2018; Wang, 2015; 2016). Another positive attribute which eventually results in students' engagement is the anonymity of Kahoot. This feature reduces the stress among students and enhances engagement among students by offering an anxiety-free environment for participation (Cutri, Marim, Cordeiro, Gil \& Guerald, 2016). That Kahoot stimulates learners' sensory and cognitive curiosity is another explanation why it keeps students engaged (Baydas \& Cicek, 2019; Bicen \& Kocakoyun, 2018). Nevertheless, some scholars have raised concerns about various factors that can affect students' engagement in a negative way. For example, Smith \& Brauer (2018) reported that poorly designed questions can affect students' engagement conversely.

The participants of the study consider motivation as the second advantage of Kahoot. They stated, 'It is so motivating to students that they do not feel they are working.' and 'students are motivated to perform well'. These findings are much in line with the current literature (Chaiyo \& Nokham, 2017; Wichadee \& Pattanapichet, 2018). This increased motivation could be due to the fact that Kahoot improves the classroom atmosphere (Aktekin, Çelebi \& Aktekin, 2018). Other possible incentives for students could be the abundance of opportunities for more intimate communication with peers (Bicen \& Kocakoyun, 2018), learning activities facilitated by Kahoot (Quadir, Chen, \& Zhang, 2018), the use of audio, graphics, music and game points in Kahoot (Baydas \& Cicek, 2019; Wang \& Lieberoth, 2016). To sum up, various interesting characteristics in Kahoot could explain why students are motivated during Kahoot quizzes.

The third advantage of Kahoot in teachers' idea is its effect on the classroom dynamics. As several participants suggested, 'it is a great way to break up the monotony in the class.' This finding is much similar to the previous works on the connection between Kahoot and class dynamics (Bawa, 2019; Cutri et al., 2016; Fotaris et al., 2016; Licorish et al. 2018; Susanti, 2017). In fact, the findings of this study corroborate previous studies that have reported using Kahoot has no negative effect on classroom dynamics (Wang \& Tahir, 2020). Kahoot can affect the classroom dynamics quickly due to the usage of rewarding points and music/audio (Wang \& Lieberoth, 2016). Another explanation could be the positive and stress-free atmosphere that Kahoot creates (Aktekin, Çelebi, \& Aktekin, 2018; Budiati, 2017; Lee et al., 2019; Turan \& Meral, 2018). This positive environment is really essential because some teachers are afraid that the competitive gaming elements in Kahoot will create anxiety for the students, resulting in ruining their motivation to learn (Zarzycka-Piskorz, 2016). All these features enable Kahoot to thrill students in the class and that is what every teacher is looking for.

Another advantage of Kahoot is that it provides both teachers and students with instantaneous feedback. As a couple 
of the participants noted, 'One of the benefits is seeing immediate results of quizzes.' The finding accords with that of Wang (2015) that the curiosity of students is activated by immediate feedback. Whitton (2011) also claims that technologies like Kahoot yield opportunities for self-assessment through providing immediate feedback. Additionally, Ismail and Mohammad (2017) and Sprague (2019) reported that students found the timely feedback very helpful in providing immediate results about their progress. Besides, immediate feedback is more effective than the delayed one in helping students to achieve better performance, especially low-ability learners. Several scholars have claimed that students prefer and spend more time reading immediate feedback (van der Kleij, Eggen, Timmers \& Veldkamp, 2012). What is more, previous studies have pointed out that immediate feedback can enhance cognitive and metacognitive performance, self-efficacy, engagement, motivation, and learning outcomes (Nkhomas, Nkhomas, Thoms, Tu, \& Le, 2018).

An additional benefit of Kahoot is that it boosts energy level in students. Three participants has pointed this out by suggesting, 'It raises the energy level in students.' This finding is similar to that of Susanti (2017) where she claims that Kahoot wakes up students from their nap makes students' eyes open widely during the class. It is also in line with those of Bicen \& Kocakoyun (2018) and Medina \& Hurtado (2017) in seeing Kahoot a positive tool for increasing the energy level among the students. The main basis for this advantage of Kahoot is to a great extent owing to the fun learning environment that it creates for learners (Ismail \& Mohammad, 2017; Licorish et al., 2017; Licorish et al., 2018). This positive change in students' energy level leads to a lively classroom dynamic (Licorish et al., 2018). Similarly, Bicen and Kocakoyun (2018) argue that this positive energy might also affect students' motivation and increase meaningfulness in the activities.

The final favorable benefit of Kahoot in teachers' perception is that it allows for review. Kahoot gives the review opportunity to both learners and teachers. After each question in Kahoot, the results for that question pops up, giving the student the chance to digest any potentially difficult question by reviewing the question once again. It also allows the teachers to review the results for each question, individuals and the whole class. The finding is in agreement with those of Bawa (2019) and Licorish et al. (2017), where they reported Kahoot as a great review tool for students and teachers. Furthermore, Thomas (2014) stated that Kahoot is really beneficial in reviewing old lesson contents. The provision of review from various perspectives by Kahoot is probably one of the features which enhances the popularity of this tool.

\subsection{Disadvantages of Kahoot}

The teachers also expressed their ideas about the disadvantages of Kahoot platform in a second Mentimeter slide. A second word cloud was created (Figure 4) for the potential weaknesses of Kahoot. The common features were extracted accordingly and presented in the form a table (Table 2).

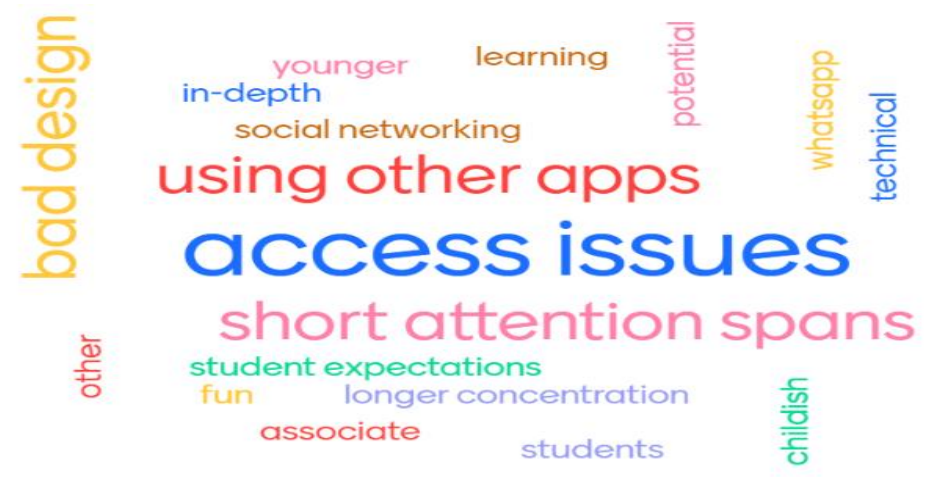

Figure 4. Word cloud of qualitative data regarding Kahoot disadvantages

As Table 2 illustrates, there were 5 common themes among the participants' ideas. Firstly, seven teachers believe that the main drawback of Kahoot is technical and access issues. Six teachers have stated that students use other applications during the Kahoot quizzes. Four think that the design of Kahoot is not good and another two feel that it leads to shorter attention spans. The last comment pertains to Kahoot's negative effect on students' expectations of the classroom. 
Table 2. Teachers' comments on the drawbacks of Kahoot

\begin{tabular}{lc}
\hline Comment & Count \\
\hline Access issues & 5 \\
Students' using other apps & 3 \\
Bad design & 2 \\
Shorter attention span & 1 \\
Student expectation & 1 \\
\hline Total & 12
\end{tabular}

From the interviewed teachers' point of view, the first demerit with Kahoot is that several students face some technical or access issues in Kahoot quizzes. These teachers stated, 'there are some potential technical problems' and 'access issues'. These technical issues in Kahoot have been reported by several previous studies (Chiang, 2020; Saracoglu \& Kocabatmaz, 2019; Wang \& Tahir, 2020). Nevertheless, this issue is mostly associated with internet availability and not the platform (Al Awadhi, 2019). The negative ideas about technical and access issued in this study could also be explained in the same way. As far as SQU campus and classes are concerned, most of the students are connected to the same network which might cause problems at times due to over-crowdedness.

Secondly, teachers point out that students use other applications in the middle of Kahoot quizzes. One of the participants have commented, 'students use other applications to waste time'. Another teacher raised the same concern when he/she mentioned, 'students go to WhatsApp and other social networking sites. This lack of attention could be caused by multiple reasons. Firstly, as Licorish et al. (2018) notes, students may grow bored once they are accustomed to a game-show learning environment. In another survey, Wang's (2015) showed that repeated use of Kahoot changed students' perception slightly over time regarding user-friendliness, engagement, and motivation which led to a slight 'wear-out effect' of classroom dynamics. What is more, Plump and LaRosa (2017) also reported that once students get several wrong answers, it was hard for them to stay motivated and engaged. Another possible explanation to this lack of interest is that some students do not like being ranked and that is not always appealing to them (Singer, 2016). In the same vein, Ipeirotis and Gabrilovich (2015) concluded that those low-ranked students on the scoreboard may be demotivated as they get lower scores than their classmates, which eventually results in negative effects on students' participation. It can be argued that despite the fact that Kahoot entertains users most of the time, lack of engagement and attention cause some students to be distracted.

The design of Kahoot is what the participants of the study see as another drawback of this platform. One participant said, 'It is a bit childish in its design and seems it was meant for younger students'. The findings are on the contrary with much of the recent literature (Batsila \& Tsihouridis, 2018; Bicen \& Kocakoyun, 2018; Wang \& Tahir, 2020). The two participants in the present study believe that the design of Kahoot is seemingly not suitable for academic centers similar to CPS because, from their perspective, the design is immature. Using just basic colors and shapes, with the least flexibility in terms of settings might be the possible reasons behind the teacher's dissatisfaction with the design of Kahoot.

The next point in teachers' view is that Kahoot shortens students' attention spans. A couple of participants of the study have commented, 'enabling shorter and shorter attention spans' and 'resulting in shorter attention spans among students.' These findings are in disagreement with most of the previous literature on GSRS. Wang and Lieberoth (2016), Plump and LaRosa (2017), Licorish et al. (2018) described GSRS as tools resulting in higher levels of focus during lectures. In their idea, the excitement generated by Kahoot encourages students to concentrate more during quizzes, enhances their attention and improves content mastery. Like any other teaching tool, using Kahoot repetitively might probably cause students to focus only on the game features and forget about the learning aspect of the quizzes.

Last but not least among teachers' perceptions of negative aspects of Kahoot is its role in forming undesired expectations among students. 'They always expect the learning to be fun and games', one participant said. This is to some extent similar to the findings of Batsila \& Tsihouridis (2018), where they state today's students are efficient users of technology and are aware of the latest technological developments. As a consequence, these digital skills raise their expectations for more exciting and innovative teaching methods and tools. However, in their study, they did not see it as a negative aspect of these kinds of teaching tools. They think that teachers could attract their students' attention to make the lesson more interesting by turning it into a game. One possible explanation could be 
that some teachers use Kahoot abundantly. When a teacher incorporates game elements more than necessary, the students would probably expect the same for all their classes.

\subsection{Practical Implications}

The findings of the present study have several implications that can benefit those teachers who plan to run Kahoot quizzes in their classes:

\section{Negotiate the objectives with students}

Before starting the Kahoot game, it is recommended that the teacher clearly explain the goals and procedures of that specific quiz to the students. They should realize that there is an academic goal behind Kahoot quizzes and that they are not merely a means of entertainment. That would encourage concentration and engagement among the audience.

\section{Use Kahoot features to engage students}

Kahoot platform has two separate unique modes. In the on-time mode, students do the quiz at the same time in the class. On the other hand, in the challenge mode, teachers assign a quiz to the students with deadline to finish it. Utilizing this challenge mode of Kahoot is another alternative that can help teachers save time, monitor students' progress individually, detect difficult questions for students and analyze the overall performance of the class on each question. Kahoot provides its user with various properties to make this digital tool more engaging. Adding multimodal features can help engage the audience if applied in the right time.

\section{Use Kahoot to motivate all types of learners}

When a teacher encounters several unmotivated students in the classroom, one of the several choices to reverse the situation is the use of Kahoot. Due to its game features, it attracts students' attention so fast. If you have a class which is difficult to start because of the noisy or shy students, a Kahoot at the beginning of the session can pave the way for the whole class.

\section{Utilize Kahoot in accordance with the class dynamics and energy level}

Running a short Kahoot quiz can refresh any class by inserting some fun into the soul of the class. Kahoot is able to improve the energy level of the class and students in the English classes. It is recommended to run Kahoot when the dynamics of the class is affected by the length and monotony of the class. Additionally, it is a good idea to run the Kahoot quizzes when the energy level of the class has diminished and you need to nudge your students.

\section{Feedback immediately}

Teachers can benefit from the immediate feedback system of Kahoot when double-checking whether all the class has understood the lesson/point. The instant feedback of Kahoot helps teachers to identify the common mistakes among students and plan on how to mend it further on.

\section{Employ Kahoot as a tool to revise the lessons}

After a session, Kahoot quizzes are a great link between the students' previous and next class as these quizzes offer revision of the material using fun and game features.

\section{Schedule your Kahoot}

Teachers/lecturers ought to be careful about how much they use Kahoot in their classes. Running Kahoot repetitively can result in boredom among students. It could also result in unreasonable expectations among them. Deciding on the appropriate time for playing Kahoot in the class depends on individual context and teacher's expediency.

\section{Minimize the negative effects of Kahoot}

Supplementing Kahoot quizzes with test-like practices can minimize the short attention span which could be caused by Kahoot games. After all, teachers need to consider the disadvantages of Kahoot and think twice before conducting a Kahoot quiz in their class.

\section{Monitor your students}

It is recommended that teachers check the availability of internet with all the participants before running a Kahoot quiz. During the quizzes, the teachers need to keep an eye on the students so that they do not get distracted by other applications on their devices. Furthermore, the teachers are advised to keep track of individual student's progress in Kahoot quizzes.

\section{Diversify your digital game-based tools}

Last but not least, if teachers intend to game-based features into their classes, they are advised to familiarize 
themselves with other digital game-based tools to make the most of these helpful gadgets. That would probably enhance the flexibility of teachers in their classes by helping them exploit all the existing potential of these teaching aids.

\section{Conclusion}

Despite the popularity of applying GSRS tools, specifically Kahoot, in classrooms around the world, only few studies have investigated how teachers perceive of this game-based tool. Most of the studies on Kahoot target its various learning effects on students' motivation, engagement, anxiety and perceptions. Despite several studies have been conducted on Kahoot, the role of teachers' perception in understanding this phenomenon better has been neglected, specifically in GCC context. As a result, the present study tried to shed some light on the topic by delving into the ideas of 13 teachers who have used Kahoot in their English classes, for Foundation or credit courses at a university in Oman. The results of the study show that participants of the study have both positive and negative views on Kahoot. As far as the benefits of Kahoot are concerned, it enhances students' engagement, motivation and energy level in the classroom. Furthermore, it improves classroom dynamics, provides immediate feedback and allows revision. On the other hand, though being so beneficial in different aspects, the participants of the study believed that Kahoot has its own drawbacks. Access issues, students using other applications such as WhatsApp, bad design, negative effect on students' attention span and expectation are some the weaknesses reported by the participants of the study. Despite the fact that many previous studies have mentioned several advantages for Kahoot, there are still some areas which seemingly require adjustments and modifications in order to maximize the efficiency of this game-based tool. In line with the findings of the present study, Sprague (2019) concludes that the advantages of GSRS outweigh the disadvantages after considering the amount of research in this area. The present study was limited in several aspects. The first limitation of the study could be the low number of participants. A further limitation is that the participants are all working in the same academic place. Further studies could be conducted on how to minimize the negative effects of Kahoot in the learning environment. Other studies can compare the perceptions of teachers and students on various dimensions of Kahoot. Additionally, using mixed-methods design might also yield more in-depth insight into this popular online tool.

\section{References}

Aktekin, N. Ç., Çelebi, H., \& Aktekin, M. (2018). Let's Kahoot Anatomy. International Journal of Morphology, 36(2), 716-721. https://doi.org/10.4067/S0717-95022018000200716

Al Awadhi, A.Y. (2020). Students' perceptions of Kahoot: An exploratory mixed- method study in EFL undergraduate classrooms in the UAE. Master's thesis. The British University in Dubai, UAE. https://doi.org/10.1007/s10639-020-10425-8

Atherton, P. (2018). More than just a quiz: How Kahoot! Can help trainee teachers understand the learning process. Teacher Education Advancement Network Journal, 10(2), 29-39.

Bawa, P. (2019). Using kahoot to inspire. Journal of Educational Technology Systems, 47(3), 373-390. https://doi.org/10.1177/0047239518804173

Baydas, O., \& Cicek, M. (2019). The examination of the gamification process in undergraduate education: A scale development study. Technology: Pedagogy and Education. https://doi.org/10.1080/1475939X.2019.1580609

Bicen, H., \& Kocakoyun, S. (2018). Perceptions of students for gamification approach: Kahoot as a case study. International Journal of Emerging Technologies in Learning (iJET), 13(2), 72-93. https://doi.org/10.3991/ijet.v13i02.7467

Budiati, B. (2017). ICT (information and communication technology) use: Kahoot program for English students'learning booster. In Proceedings education and language international conference (Vol. 1).

Celik, U., Akcetin, E., \& Asmali, M. (2016). Game Based Learning by Using Student Response Systems. 6th International Conference on "Innovations in Learning for the Future": Next Generation. İstanbul, Turkey.

Chaiyo, Y., \& Nokham, R. (2017). The effect of Kahoot, Quizizz and Google Forms on the student's perception in the classrooms response system. International conference on Digital arts, media and technology (ICDAMT), (pp. 178-182). IEEE. https://doi.org/10.1109/ICDAMT.2017.7904957

Chiang, H. H. (2020). Kahoot In an EFL reading Class. Journal of Language Teaching and Research, 11(1), 33-44. https://doi.org/10.17507/jltr.1101.05

Chien, C. W. (2015). Analysis the effectiveness of three online vocabulary flashcard websites on L2 learners' level of 
lexical knowledge. English Language Teaching, 8(5), 111-121. https://doi.org/10.5539/elt.v8n5p111

Chumairok \& Ardiyani, D. K. (2020). Kahoot: Alternative learning media in the millennial era. International seminar on language, education, and Culture, Social Sciences, 57-61.

Cutri, R., Marim, L. R., Cordeiro, J. R., Gil, H. A. C., \& Guerald, C. C. T. (2016). Kahoot, a new and cheap way to get classroom-response instead of using clickers. In Proceedings of American society for engineering education conference, 26-29. USA: New Orleans. https://doi.org/10.18260/p.25512

de Sousa, B. F. P. (2018). Engaging students in the evaluation process using co-creation and technology enhanced learning (CC-TEL). In CC-TEL. Leeds, UK.

Dervan, P. (2014). Increasing in-class student engagement using Socrative (an online student response system). AISHE-J: The All Ireland Journal of Teaching and Learning in Higher Education, 6(3), 1-13.

Fotaris, P., Mastoras, T., Leinfellner, R., \& Rosunally, Y. (2016). Climbing up the leaderboard: An empirical study of applying gamification techniques to a computer programming class. Electronic Journal of E-Learning, 14(2), 94-110.

Gee, J. P. (2003). What video games have to teach us about learning and literacy. New York, Palgrave/Macmillan. https://doi.org/10.1145/950566.950595

Hadijah, Pratolo, B. W., \& Rondiyah. (2020). Interactive game "Kahoot" as the media of students' vocabulary assessment. Journal on English as a Foreign Language, 10(1), 84-102. https://doi.org/10.23971/jefl.v10i1.1670

Ipeirotis, P. G., and Gabrilovich, E. (2015). Quizz: Targeted crowdsourcing with a billion (potential) users. International Conference on World Wide Web, 143-154. https://doi.org/10.1145/2566486.2567988

Ismail, M. A. A., \& Mohammad, J. A. M. (2017). Kahoot: A promising tool for formative assessment in medical education. Education in Medicine Journal, 9(2), 19-26. https://doi.org/10.21315/eimj2017.9.2.2

Law, E. L. C., \& Sun, X. (2012). Evaluating user experience of adaptive digital educational games with Activity Theory. International Journal of Human-Computer Studies, 70(7), 478-497. https://doi.org/10.1016/j.ijhcs.2012.01.007

Lee, C. C., Hao, Y., Lee, K. S., Sim, S. C., \& Huang, C. C. (2019). Investigation of the effects of an online instant response system on students in a middle school of a rural area. Computers in Human Behavior, 95, 217-223. https://doi.org/10.1016/j.chb.2018.11.034

Licorish A. S., Owen, H. E., Daniel, B. \& George, J. L. (2018). Students' perception of Kahoot's influence on teaching and learning. Research and Practice in Technology Enhanced Learning, 13(9), 1-23. https://doi.org/10.1186/s41039-018-0078-8

Liu, O. L., Bridgeman, B., \& Adler, R. M. (2012). Measuring learning outcomes in higher education: Motivation matters. Educational Researcher, 41(9), 352-362. https://doi.org/10.3102/0013189X12459679

Liu, X., \& Wang, L. C. C. (2017). Motivation, learning strategies, and language competency in a technology facilitated Chinese as a second language classroom. Chinese Language Teaching Methodology and Technology, l(2), 1-8.

Malone, T. W. (1981). Toward a theory of intrinsically motivating instruction. Cognitive science, 5(4), 333-369. https://doi.org/10.1207/s15516709cog0504_2

Mohan, B. S., Nambiar, V., \& Arvindakshan, R. (2018). Implementation and assessment of students' perception on effectiveness of Kahoot game-based educational tool in learning microbiology. Journal of Biomedical and Pharmaceutical Research, 7(4), 12-18.

Muncy, J. A., \& Eastman, J. K. (2012). Using classroom response technology to create an active learning environment in marketing classes. American Journal of Business Education, 2(2), 213-218. https://doi.org/10.19030/ajbe.v5i2.6824

Nacke, L. E., Drachen, A., \& Göbel, S. (2010). Methods for evaluating gameplay experience in a serious gaming context. International Journal of Computer Science in Sport, 9(2), 1-12.

Nkhoma, C., Nkhoma, M., Thomas, S., \& Tu, L. (2018). Gamifying a flipped first year accounting classroom using Kahoot!. International Journal of Information system and engineering, 6(1), 93-115. https://doi.org/10.24924/ijise/2018.11/v6.iss2/93.115 
Paraskeva, F., Mysirlaki, S., \& Papagianni, A. (2010). Multiplayer online games as educational tools: Facing new challenges in learning. Computers \& Education, 54(2), 498-505. https://doi.org/10.1016/j.compedu.2009.09.001

Parra-Santos, T., Molina-Jordá, J. M., Casanova-Pastor G. \& Maiorano-Lauria, L. P. (2018). Gamification for formative assessment in the framework of engineering learning. In Proceedings of the 6th International Conference on Technological Ecosystems for Enhancing Multiculturality (pp. 61-65). ACM, New York, USA. https://doi.org/10.1145/3284179.3284193

Pivec, M. (2007). Editorial: Play and learn: Potentials of game-based learning. British Journal of Educational Technology, 38(3), 387-393. https://doi.org/10.1111/j.1467-8535.2007.00722.x

Plump, C. \& LaRosa, J. (2017). Using Kahoot in the Classroom to Create Engagement and Active Learning: A Game-Based Technology Solution for eLearning Novices. Management Teaching Review, 2(2), 151-158. https://doi.org/10.1177/2379298116689783

Quadir, B., Chen, N. S., \& Zhang, J. (2018). Learner satisfaction toward using IRS in synchronous sessions of an online course. In Proceedings of the 4th international conference on frontiers of educational technologies (pp. 10-15). ACM. https://doi.org/10.1145/3233347.3233354

Rosas, R., Nussbaum, M., Cumsille, P., Marianov, V., Correa, M., \& Flores, P. (2003). Beyond nintendo: Design and assessment of educational video games for first and second grade students. Computers and Education, 40(1), 71-94. https://doi.org/10.1016/S0360-1315(02)00099-4

Ryan, G. W., \& Bernard, H. R. (2003). Techniques to Identify Themes. Field Methods, 15(1), 85-109. https://doi.org/10.1177/1525822X02239569

Saracoglu, G., \& Kocabatmaz, H. (2019). A Study on Kahoot and Socrative in Line with Preservice Teachers' views. Educational Policy Analysis and Strategic Research, 14(4), 31-46. https://doi.org/10.29329/epasr.2019.220.2

Sharples, M. (2000). The design of personal mobile technologies for lifelong learning. Computer \& Education, 34(3), 177-193. https://doi.org/10.1016/S0360-1315(99)00044-5

Siau, K., Sheng, H., \& Fui-Hoon, N. F. (2006). Use of a classroom response system to enhance classroom interactivity. Management Department Faculty Publications, 49(3), 398-403. https://doi.org/10.1109/TE.2006.879802

Singer, N. (2016). Kahoot app brings urgency of a quiz show to the classroom. Retrieved from https://www.nytimes.com/2016/04/17/technology/kahoot-app-brings-urgency-of-a-quiz-show-to-the-classroom. html

Smith, A., \& Brauer, S. (2018). T1-A: Use of Kahoot games for increased motivation and understanding in a thermodynamics course. In 2018 ASEE southeastern section conference.

Sprague, A. (2016). Improving the ESL graduate writing classroom using Socrative: (Re)considering exit tickets. TESOL Journal, 7(4), 989-998. https://doi.org/10.1002/tesj.295

Sprague, A. (2019). Using Kahoot jumble to teach paragraphing in the writing classroom. Retrieved from https://wisconsinenglishjournal.org/2019/05/04/a-sprague/

Steinert, Y., \& Snell, L. S. (1999). Interactive lecturing: Strategies for increasing participation in large group presentations. Medical Teacher, 21(1), 37-42. https://doi.org/10.1080/01421599980011

Susanti, S. (2017). Fun activities in teaching English by using Kahoot. In 2nd international seminar on education. Batusangkar, Indonesia.

Thomas, C. (2014). Kahoot. Retrieved January 17, 2015, from https://www.graphite.org/website/kahoot

Tsymbal, S. (2018). Gamified training sessions as means of enhancing students' motivation in learning English. Psychological Journal, 17(7), 151-161. https://doi.org/10.31108/1.2018.7.17.10

Turan, Z., \& Meral, E. (2018). Game-based versus to non-game-based: The impact of student response systems on students' achievements, engagements and test anxieties. Informatics in Education, 17(1), 105-16. https://doi.org/10.15388/infedu.2018.07

van der Kleij, F. M., Eggen, T. J., Timmers, C. F., \& Veldkamp, B. P. (2012). Effects of feedback in a computer-based assessment for learning. Computers \& Education, $263-272$. https://doi.org/10.1016/j.compedu.2011.07.020 
Vick, I. (2019). Training professionals from three countries share their Kahoot'ing experience (Vol. 2019). https://kahoot.com/blog/2019/09/10/top-training-tipskahoot-around-world/: Kahoot.

Wang, A. I. (2015). The wear out effect of a game-based student response system. Computers \& Education, 82, 217-227. https://doi.org/10.1016/j.compedu.2014.11.004

Wang, A. I., \& Lieberoth, A. (2016). The effect of points and audio on concentration, engagement, enjoyment, learning, motivation, and classroom dynamics using Kahoot. In Proceedings from the 10th European conference of games-based learning. Academic Conferences and Publishing International Limited.

Wang, A. I., \& Lieberoth, A. (2016). The effect of points and audio on concentration, engagement, enjoyment, learning, motivation, and classroom dynamics using Kahoot. In Proceedings from the 10th European Conference on Games Based Learning, (p. 738). Reading, UK: Academic Conferences International Limited.

Wang, A. I., \& Tahir, R. (2020). The effect of using Kahoot for learning: A literature review. Computers \& Education, 149, 1-22. https://doi.org/10.1016/j.compedu.2020.103818

Wang, A. I., Zhu, M., \& Sætre, R. (2016). The effect of digitizing and gamifying quizzing in classrooms. In European conference on games-based learning. Paisley, Scotland: Academic Conferences and Publishing International.

Whitton, N. (2011). Game engagement theory and adult learning, simulation \& gaming. An Interdisciplinary Journal, 42(5), 596-609. https://doi.org/10.1177/1046878110378587

Wichadee, S., \& Pattanapichet, F. (2018). Enhancement of performance and motivation through application of digital games in an English language class. Teaching English with Technology, 18(1), 77-92.

Yapıc1, I. Ü., \& Karakoyun, F. (2017). Gamification in biology teaching: A sample of Kahoot application. Turkish Online Journal of Qualitative Inquiry, 8(4), 396-414. https://doi.org/10.17569/tojqi.335956

Yürük, N. (2020). Using Kahoot as a skill improvement technique in pronunciation. Journal of Language and Linguistic Studies, 16(1), 137-153. https://doi.org/10.17263/jlls.712669

Zarzycka-Piskorz, E. (2016). Kahoot it or not? Can games Be motivating in learning grammar? Teaching English with Technology, 16(3), 17-36.

\section{Copyrights}

Copyright for this article is retained by the author(s), with first publication rights granted to the journal.

This is an open-access article distributed under the terms and conditions of the Creative Commons Attribution license (http://creativecommons.org/licenses/by/4.0/). 